\title{
THE EFFECT OF BIOGAS WASTE ON NUTRIENT CONTENTS AND MUSTARD PLANTS (BRASSICA JU NCEA L.) PERFORMANCES
}

\author{
Mochammad Junus ${ }^{1}$, Hary Nugroho ${ }^{1}$, Eggi Pur Pinandita ${ }^{\circledR}$, Shafa Fa'izah ${ }^{2}$ and Dia \\ Fadilah $^{2}$ \\ ${ }^{1}$ Lecturer in Animal Production, Faculty of Animal Science, Brawijaya University, Malang, Indonesia \\ ${ }^{2}$ Student of the Faculty of Animal Science, Brawijaya University, Malang, Indonesia
}

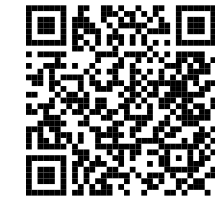

Received 6 May 2021

Accepted 20 May 2021

Published 31 May 2021

Corresponding Author

Mochammad Junus, junusbrawijay

a@yahoo.com

DOI $10.29121 /$

granthaalayah.v9.i5.2021.3920

Funding: This research received no specific grant from any funding agency in the public, commercial, or not-for-profit sectors.

Copyright: (C) 2021 The Author(s). This is an open access article distributed under the terms of the Creative Commons Attribution License, which permits unrestricted use, distribution, and reproduction in any medium, provided the original author and source are credited.

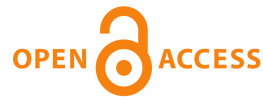

\section{ABSTRACT}

The aim of research to determine the effect of sludge that mixed with plant waste and livestock waste on soil nutrient content and Brassica juncea L. performances. The research method used was the experiment of adding local microorganism solution (LMS) of banana weevil, coconut fiber ash and eggshell flour into sludge of quail and octopus waste as organic fertilizer with a completely randomized design (CRD) method with 6 treatments and 4 replications . The treatments used consisted of P0: sludge 100\%; P1 : sludge 50\% + LMS $20 \%+$ Ash $10 \%+$ Eggshell Flour 20\%; P2: sludge 50\% + LMS 20\% + Ash $12.5 \%$ + Eggshell Flour 17.5\%; P3: sludge 50\% + LMS 20\% + Ash 15\% + Eggshell Flour 15\%; P4: sludge 50\% + LMS 20\% + Ash 17.5\% + Eggshell Flour 12.5\% and P5: sludge 50\% + LM S 20\% + Ash 20\% + Eggshell Flour 10\%. The result showed that the treatment given had a very significant effect $(\mathrm{P}<0.01)$ on the total $\mathrm{N}$ content, elements $\mathrm{P}$ and $\mathrm{K}$, but the highest average was obtained from P0 (100\% sludge), so it can be concluded that substit ution had no effect on nutrient content. The average of total $\mathrm{N}$ values ranged from $1.15 \pm 0.10$ to 2.39 \pm 0.40 percent, element $P$ ranges from $2.65 \pm 0.19$ to $5.28 \pm 0.19$ percent and element $\mathrm{K}$ ranges from $1.08 \pm 0.05$ to $4.28 \pm 0.21$ percent. And for Brassica juncea L. pe rformance this treatment give a real effect $(\mathrm{P}<0.01)$ to the height and weight of a mustard plant wet and did not give an effect $(\mathrm{P}<0.05)$ to the number of leaves of mustard plants. The conclusion of this study are the mixed sludge waste had a significant effect on soil nutrient content and on Brassica juncea L. performance.

Keywords: Mixed Bio Slude, Fertilizer, Nutrient Content, Mustard Plant

\section{INTRODUCTION}

Biogas waste, including those from quail cattle, is currently only used as fertilizer, with the increasing interest in quail consumption it will encourage an increase in the 
quail population. The results of records from the Ministry of Agriculture, Directorate General of Animal Husbandry and Animal Health (2018) Anonymous (2018) that the population of various livestock has increased from 2016 with an increase in quail population by $3.42 \%$ or as much as 14.6 million heads. Apart from waste from the livestock sector, there is also waste from the fisheries sector which is engaged in the canned fish processing industry. One of the commodities processed in the canned fish processing industry is octopus. Supriyanto et al. (2018), in octopus processing waste, the waste produced is in the form of liquid waste that is red in color and has not maximally utilized its waste, causing a high level of waste production that has not been reused. Livestock waste stored in closed spaces can produce bio gas ( $\mathrm{CH}$ 4 ) which can cause air pollution. The level of gas emissions $\mathrm{CH}_{4}$ dip engaruhi by many factors, such as composition and feed conversion, animal waste handling and environmental conditions Broucek and Bohuslav (2015). Quail livestock waste can be processed into energy through digestion tanks which produce the main product in the form of bio gas and a byproduct in the form of organic lumpr (sludge) .

Organic sludge contains nutrients and can still be used as fertilizer for plants. Jonah (2006) stated that l umpur organic is the solution of waste products of manufacture of bio-gas which still contains ingredients organic portion is not biodegradable. The nutritional content of organic sludge is good enough for the feed chart because it still contains $13.3 \%$ protein, $24.3 \%$ crude fiber and $3651 \mathrm{kcal} / \mathrm{kg}$ energy. Organic sludge is processed into fertilizer orga ni $\mathrm{k}$ is added with other organic waste to supplement the content of nutrients in the fertilizer.

The use of LMS (local microorganism solution ) of banana weevil as a decomposer for oil palm empty bunches can increase the total $\mathrm{N}$ content which is bigger than the use of EM 4 as a decomposer for oil palm empty bunches Supriyanto et al. (2018). According to research by Risnah, Prapto and Abdul (2013), it shows that the characteristics of coconut husk ash from the results of the analysis show a high $\mathrm{pH}$ condition of 11.77 and a high total $\mathrm{K}$ content of $21.87 \%$ and a good cation exchange capacity value of 13. , $29 \mathrm{me} / 100 \mathrm{~g}$. Egg shell waste can be used as additional fertilizer as a source of calcium and phosphorus. Isniati (20 09) states that the nutrients in the compost yield with the addition of eggshell flour produce nutrients with an average percentage of $\mathrm{N}, \mathrm{P}, \mathrm{K}$, namely $\mathrm{N}=0.675 \%, \mathrm{P}=49.553 \%$, and $\mathrm{K}=0.767 \%$.

Based on the description above, it is necessary to conduct research on a mixture of organic sludge with other wastes on soil nutrient content and on the appearance of mustard greens ( Brassica juncea L. ).

\section{MATERIALS AND METHODS}

The materials used are digital scales, plastic bucket, knive, pH meter, pot tray, polybag, soil and Brassica juncea L. seeds. The fertilizer materials are sludge based of quail and octopus waste that mixed with local microorganism solution ( LMS ) , egg shell flour and coconut ash as organic fertilizer with a completely randomized design 
(CRD) method with 6 treatments and 4 replications. The treatments used consisted of :

$$
\begin{aligned}
& \text { P0 = sludge } 100 \% \\
& \text { P1 = sludge } 50 \%+\text { LMS } 20 \%+\text { Ash } 10 \%+\text { Eggshell Flour } 20 \% \\
& \text { P2 = sludge } 50 \%+\text { LMS } 20 \%+\text { Ash } 12.5 \%+\text { Eggshell Flour } 17.5 \% \\
& \text { P3 = sludge } 50 \%+\text { LMS } 20 \%+\text { Ash } 15 \%+\text { Eggshell Flour } 15 \% \\
& \text { P4 = sludge } 50 \%+\text { LMS } 20 \%+\text { Ash } 17.5 \%+\text { Eggshell Flour } 12.5 \% \\
& \text { P5 = sludge } 50 \%+\text { LMS } 20 \%+\text { Ash } 20 \%+\text { Eggshell Flour } 10 \% .
\end{aligned}
$$

Every tratments are packed in $1 \mathrm{~kg}$ sized plastic bag and analyzed in Soil, Plant, Fertilizer and Water Laboratory of Agricultural Technology Research Center Malang, East Java . After being analyzed, the fertilizer is applied to the mustard plant (Brassica juncea L. ).

The observed variables include the nutrient s (N, P, and $\mathrm{K}$ ) , plant's height, number of leaves and harvest weight. The results of the observation were analyzed by variance if there were differences tested by using the Duncan Multiple Range Test.

\section{RESULTS AND DISCUSSION}

\subsection{NITROGEN (N) CONTENT}

Based on observations and calculations show that there is difference to the $\mathrm{N}$ total content in fertilizer $(\mathrm{P}<0.01)$ that can be seen in Table 1 .

\section{Table 1 The average of Nitrogen $(\mathrm{N})$ content}

\begin{tabular}{cc}
\hline Treatments & Average of N Total content (\%) \\
P0 & $2.39 \pm 0.40^{b}$ \\
P1 & $1.56 \pm 0.29^{a}$ \\
P2 & $1.15 \pm 0.10^{a}$ \\
P3 & $1.35 \pm 0.12^{a}$ \\
P4 & $1.18 \pm 0.03^{a}$ \\
P5 & $1.36 \pm 0.08^{a}$ \\
\hline
\end{tabular}

The results of laboratory analysis showed that the highest total $\mathrm{N}$ average was obtained from treatment P0 $(2.39 \pm 0.40)$ which was a control treatment with a fertilizer concentration of $100 \%$ sludge based on quail and octopus waste. This shows that the sludge based on quail and octopus waste has a high total $\mathrm{N}$ content without addition. The high total $\mathrm{N}$ content in the sludge is caused by the organic matter fermentation process that occurs in the digester. Quail manure in the form of excreta has a high $\mathrm{N}$ content supported by high protein feed. In accordance with the opinion of Suhartana et al. (2017) that the increase in total N content is due to the decomposition of the sludge material by microorganisms that convert ammonia to nitrate.

$\mathrm{N}$ element is the main nutrient for plant growth because it is a constituent of all proteins and nucleic acids and is a constituent of the protoplasm as a whole Kusuma 
and Erviana (2012), this is in accordance with the results of the analysis that the biogas unit waste contains nitrogen which is readily utilized by plant roots as sources of nutrient $\mathrm{N}$ for the plants through the process of estab UPUK an organic sludge.

\subsection{PHOSPHATE (P) CONTENT}

Based on observations and calculations show that there is difference to the P content in fertilizer $(\mathrm{P}<0.01)$ that can be seen in Table 2 .

\begin{tabular}{cc}
$\begin{array}{c}\text { Table } 2 \\
\text { The average of Phosphate (P) } \\
\text { content }\end{array}$ \\
\hline Treatments & Average of P content (\%) \\
\hline P0 & $5.28 \pm 0.19^{b}$ \\
P1 & $2.65 \pm 0.19^{a}$ \\
P2 & $2.65 \pm 0.24^{a}$ \\
P3 & $2.83 \pm 0.18^{a}$ \\
\hline P4 & $3.01 \pm 0.21^{a}$ \\
P5 & $2.91 \pm 0.07^{a}$ \\
\hline
\end{tabular}

The average results showed that the highest $\mathrm{P}$ content was obtained from treatment P0 (5.28 \pm 0.19$)$ which is a treatment with $100 \%$ fertilizer concentration sludge based on quail and octopus waste. The addition of eggshell flour which was intended to increase the $\mathrm{P}$ content in the fertilizer did not have a significant effect because the highest $\mathrm{P}$ content was found in the P0 treatment.

The high content of $\mathrm{P}$ elements comes from quail dung which is a poultry farm. This is supported by the opinion of Biyatmoko et al. (2011)which states that the highest $\mathrm{P}$ content is produced by biogas made from duck dung, reaching $1.33 \%$. This is because the poultry manure used comes from poultry that are in the production phase for eggshell formation. The high $\mathrm{P}$ content is proportional to the $\mathrm{N}$ content in the fertilizer. The greater the nitrogen contained, the multiplication of microorganisms that break down the phosphorus will increase, so that the phosphorus content in the compost material also increases Hidayati et al. (2011).

\subsection{POTASSIUM (K) CONTENT}

Based on observations and calculations show that there is differenc e to the K content in fertilizer $(\mathrm{P}<0.01)$ that can be seen in Table 3 .

$\mathrm{H}$ acyl flats showed the highest K element content derived from treatment P4 (4.28 \pm 0.21 ) but not significantly different from treatment P5 ( $4.11 \pm 0.59)$. This shows that the mixture of plant and livestock waste can increase the level of $\mathrm{K}$ in fertilizer . Fertilizer P4 with the addition of coconut husk ash as much as $17.5 \%$ gave the highest average $\mathrm{K}$ element, which means the optimal percentage of coconut husk ash to increase the $\mathrm{K}$ content in the fertilizer. 
Table 3 The average of Potassium (K) content

\begin{tabular}{cc}
\hline Treatments & Average of K content (\%) \\
\hline P0 & $1.08 \pm 0.05^{a}$ \\
P1 & $1.82 \pm 0.12^{b}$ \\
P2 & $2.37 \pm 0.16^{b}$ \\
P3 & $2.12 \pm 0.23^{b}$ \\
P4 & $4.28 \pm 0.21^{c}$ \\
P5 & $4.11 \pm 0.59^{c}$ \\
\hline
\end{tabular}

The addition of coconut husk ash is intended to increase the content of $\mathrm{K}$ in the fertilizer, this is in accordance with the statement of Risnah et al. (2013) which shows that the characteristics of coconut coir ash from the analysis results show a high $\mathrm{pH}$ content condition of 11.77 and The high total $\mathrm{K}$ content was $21.87 \%$ and the good cation exchange capacity was 13.29 me / 100g. Ash is an excellent source of the $\mathrm{K}$ element as fertilizer for crops. Ash source of the element $\mathrm{K}$ can be obtained from husk ash from agricultural waste, kitchen ash from household waste and coconut ash from plantation waste. According to Imaduddin et al. (2008) ashes from the burning of TKS (Empty Palm Fruit Bunches) have high levels of potassium (45-50\%). Elemental $\mathrm{K}$ is one of the minerals needed by plants to develop and produce. Mineral elements are one of the components indispensable for living things in addition to carbohydrates, fats, proteins and vitamins, also known as inorganic substances or ash content Arifin (2008). Minerals are inorganic substances that do not evaporate when burned so that they remain in the form of ash, therefore coconut coir burning ash has a high $\mathrm{K}$ content.

\subsection{PLANT'S HEIGHT}

Based on observations and calculations show that there is difference to the plant's height $(\mathrm{P}<0.01)$ that can be seen in Table that can be seen in Table 4 .

Table 4 The average of Plant's Height

\begin{tabular}{cc}
\hline Treatments & Average of Plant's Height (cm) \\
P0 & $18,24 \pm 1,20^{b}$ \\
P1 & $18,73 \pm 0,59^{b}$ \\
P2 & $18,68 \pm 0,88^{b}$ \\
P3 & $18,06 \pm 0,92^{b}$ \\
P4 & $15,66 \pm 0,13^{a}$ \\
P5 & $16,96 \pm 1,68^{a b}$ \\
\hline
\end{tabular}

The analysis of variance carried out on the observed data on the height of the mustard plant showed that mixing of sludge with plant and livestock waste had a significant effect $(\mathrm{P}<0.01)$ on the height of the mustard plant. This effect is thought to 
be caused by the provision of soil nutrients in the form of $\mathrm{N}, \mathrm{P}$ and $\mathrm{K}$ and other microsubstances obtained by adding fertilizers to plants. The use of organic fertilizers on plants not only provides the elements needed by plants, but can also improve soil structure (Mayaza, Susatyo and Prasetya, 2013).

It is known from Table 4 that the average yield shows the highest mustard plant height obtained from treatment P1 $(18.73 \pm 0.59)$ which is a treatment with a fertilizer concentration of $50 \%$ sludge , $20 \%$ LMS bong gol banana, $10 \%$ coconut husk ash and 20\%. eggshell flour. Treatment P1 (18.73 \pm 0.59$)$ had no different effects from P0 (18.24 \pm 1.20$), \mathrm{P} 2(18.68 \pm 0.88)$, P3 (18.06 \pm 0.92$)$. Treatment P4 with an average of $(15.66 \pm 0.13)$ shows the lowest average and has an average test result that is significantly different from other treatments. P4 treatment is a fertilizer concentration of $50 \%$ sludge , $20 \%$ LMS of banana weevil, $17.5 \%$ coconut husk ash and $10 \%$ eggshell flour.

The observations show that P1 has the highest plant height compared to other treatments. This shows that the addition of banana weevil LMS, coconut husk ash and eggshell flour can increase plant height. Fertilizer P1 with the addition of $20 \%$ egg shell flour gave the highest average of mustard greens, which means that the optimal percentage of eggshell flour is to increase the height of the mustard plant. Ariwibowo (2012) reported that chicken eggshell flour and rice washing water had a significant effect on the height of tomato plants. Furthermore, Wilda (2013) reported that giving chicken eggshell flour had a significant effect on the height and number of leaves of the cayenne pepper plant.

\subsection{NUMBER OF LEAVES}

Based on observations and calculations show that there is no difference to the number of leaves $(\mathrm{P}<0.01)$ that can be seen in Table 5 .

Table 5 The average of Number of Leaves

\begin{tabular}{cc}
\hline Treatments & Average of number of leaves (sheets) \\
P0 & $5,25 \pm 0,47$ \\
P1 & $4,86 \pm 0,48$ \\
P2 & $4,94 \pm 0,52$ \\
P3 & $4,78 \pm 0,29$ \\
P4 & $5,00 \pm 0,59$ \\
P5 & $4,83 \pm 0,45$ \\
\hline
\end{tabular}

Analysis of variance from the observed data showed that mixing of sludge with plant and livestock waste had no significant effect $(\mathrm{P}>0.05)$ on the number of mustard leaves.

It is known from Table 5 that the average results showed that the highest number of leaves was obtained from treatment P0 $(5.25 \pm 0.47)$, which is a treatment with a fertilizer concentration of $100 \%$ sludge without mixing with plant and livestock 
waste, but P0 treatment did not have a significant effect on P1, P2, P3, P4 and P5.

\subsection{HARVEST WEIGHT}

Based on observations and calculations show that there is difference to the harvest weight $(\mathrm{P}<0.01)$ that can be seen in Table 6 .

\begin{tabular}{cc}
\hline \multicolumn{2}{c}{ Table 6 The average of Harvest Weight } \\
\hline Treatments & Average of harvest weight (g) \\
P0 & $84,50 \pm 6,00^{b}$ \\
P1 & $73,13 \pm 6,88^{a b}$ \\
P2 & $76,25 \pm 12,05^{a b}$ \\
P3 & $70,25 \pm 2,56^{a b}$ \\
P4 & $62,75 \pm 3,06^{a}$ \\
P5 & $69,92 \pm 9,23^{a b}$ \\
\hline
\end{tabular}

The analysis of variance carried out on the observed data from the wet weight of the mustard plant showed that mixing of sludge with plant and livestock waste had a significant effect $(\mathrm{P}>0.05)$ on the wet weight of the mustard plant. Harjadi (1991) states that the availability of nutrients plays an important role as an energy source so that the nutrient adequacy level plays a role in influencing the biomass of a plant. Plant growth can be disrupted if there are no additional nutrients from fertilizers, which results in lower biomass.

It is known from Table 6 that the average results show the plants with the highest wet weight (gr), namely treatment P0 (84.50 \pm 6.00$)$ and significantly different from other treatments, namely P2 (76.25 \pm 12.05$),$ P1 (73, $13 \pm 6.88)$, P3 ( $70.25 \pm 2.56)$, $\mathrm{P} 5(69.92 \pm 9.23)$ and P4 $(62.75 \pm 3.06)$. This is due to differences in the concentration of sludge for each treatment. P0 has a sludge concentration of $100 \%$ while in other treatments it is 50\% sludge with $50 \%$ addition of LMS banana weevil, coconut husk ash and eggshell flour. This shows that sludge based on quail and octopus waste without mixing with plant and livestock waste can give the best results for the wet weight of mustard plants.

Judging from the results of the average observations of the wet weight of the mustard plant in Table 6, the yields do not increase significantly in line with the increase or decrease in the proportion of the organic fertilizer mixture. Starting from P0 as the control treatment in which only fertilizer made from sludge yes ng had the highest mean. Treatment P1 showed a decrease in the average then in P2 treatment gave an increase in the average value of plant wet weight. The average decline occurred again at P3 and the lowest was at P4 then there was an increase in the average at P5. In the P0 treatment which has a concentration of $100 \%$ sludge based on quail and octopus waste without mixing with plant and livestock waste. This shows that the most optimal nutrient needed to create the highest fresh weight of mustard greens is obtained from fertilizer treatment P0 which consists of $100 \%$ sludge. 


\section{CONCLUSIONS AND SUGGESTIONS}

\subsection{CONCLUSION}

1. Mixed sludge based on quail and octopus waste with plant and livestock waste doesn't affect the increase in the level of nutrient contents .

2. The best treatment for mustard plant performance is P0 which is not mixed with plant and livestock waste.

\subsection{SUGGESTION}

The application of sludge based on quail and octopus waste which are processed for fertilizer is important to improve environmental quality.

\section{REFERENCES}

Anonymous. (2018). Ministry Of Agriculture, Directorate General Of Animal Husbandry And Animal Health. In Animal Husbandry And Animal Health Statistics 2018. Directorate General Of Peter Nakan And Animal Health, Ministry Of Agriculture. Republic Of Indonesia. Jakarta.

Arifin, Z. (2008). Some Micro Essential Mineral Elements In Biological Systems And Their Analysis Methods. Journal Of Agricultural Research And Development, 27(3), 99-105.

Ariwibowo, F. (2012). Utilization Of Chicken Egg Shells And Rice Washing Water On The Growth Of Tomato (Solanum Lycopersicum) Plants With Hydroponic Growing Media. Utilization Of Chicken Egg Shells And Rice Washing Water On The Growth Of Tomato (Solanum Lycopersicum) Plants With Hydroponic Growing Media.

Biyatmoko, D., B, , \& Wijokongko. (2011). Community Perceptions Of Banjar Regency On Biogas Energy Utilization And Quality Of Biogas Waste Fertilizer. Enviro Scienteae, 7, 1-5.

Broucek, J., \& Bohuslav, C. (2015). Emission Of Harmful Gases From Poultry Farms And Possibilities Of Their Reduction. Ecologia (Bratislava). Emission Of Harmful Gases From Poultry Farms And Possibilities Of Their Reduction. Ecologia (Bratislava), 34, 89-100.

Harjadi. (1991). Introduction To Agronom I. PT Gramedia Pustaka Utama. In Introduction To Agronom I. PT Gramedia Pustaka Utama. Jakarta.

Hidayati, Y., Astuti, Tb, Benito, A., \& Kurnani. (2011). Quality Of Beef Cattle Feces Processing Liquid Fertilizer Using Saccharomyces Cereviceae. Eulis T. Marlina. And Ellin H, 11(2), 104-107.

Imaduddin, M., Yoeswono, K. W., \& Iqmal, T. (2008). Potassium Extraction From Palm Empty Bunch Ash As A Catalyst In Palm Oil Transesterification Reactions. Bulletin OfChemical Reaction Engineering \& Catalysis, 3(1-3), 14-20.

Isniati. (2009). Effect Of Addition Of Flour Flour (Eggshell) In The Composting Process Of Organic Waste. Journal Of SAINSTEK, 7(1), 1-8.

Junus, M. (2006). Techniques For Making And Utilizing Bio Gas Units. DTC. In Techniques For Making And Utilizing Bio Gas Units. DTC. Bandung Institute Of Technology. Bandung.

Kesumaningwati, R. (2015). The Use Of LMS Bump P Isang ( Musa Paradisiaca) As A Decomposer For Composting Oil Palm Empty Bunches. Ziraa'ah Journal, 40(1), 40-45.

Kusuma, M., \& Erviana. (2012). Effect Of Quail Manure Fertilizer Measurement On Growth And Yield Of Chicory ( Brassi Ca Juncea L.). Journal Of Tropical Animal Science, 1(1), 7-11. 
Risnah, S., Prapto, Y., \& Abdul, S. (2013). Effect Of Coconut Coir Ash On K Availability In Soil And K Uptake On Cocoa Seed Growth. Journal Of Agricultural Science, 16(2), 79-91.

Suhartana, Ged, E. I., S, Y., Wayan, I., \& W. (2017). Study Of Cow Manure Sludge Fermentation Process. Biosystems And Agricultural Engineering), 5(1), 1-7.

Supriyanto, G., Nisak, R. K., \& Abdulloh, A. (2018). Decolorization Of Octopus Treatment Wastewater With The AOT ( Advance Oxidation Treatment) Method. Journal of Research Chemistry, 3(1), 6-12.

Wilda, A. (2013). Effect Of Chicken Egg Shell Waste ( Gallus Gallus Domesticus ) On The Growth Of Cayenne Pepper ( Capsicum Frutescens L.). Effect Of Chicken Egg Shell Waste (Gallus Gallus Domesticus) On The Growth Of Cayenne Pepper (Capsicum Frutescens L.) And Its Teaching At SMA Negeri 9 Palembang. 